Prof. Sanja Marjanović*, LL.D.

ОРИГИНАЛНИ НАУЧНИ РАД

10.5937/zrpfn0-24511

Assistant Professor,

Faculty of Law, University of Niš

Prof. Mirko Živković*, LL.D.

Full Professor,

UDK: 341.9

Faculty of Law, University of Niš

Рад примљен: 10.12.2019.

Рад прихваћен: 26.12.2019.

\title{
SECURITY FOR COSTS IN THE 1982 PIL ACT: THE RESPONSIBILITY OF THE STATE FOR DISCRIMINATION? ${ }^{* *}$
}

\begin{abstract}
The prohibition of discrimination and the right of access to justice are guaranteed by several international treaties and the national legislation in force in the Republic of Serbia. In terms of Private International Law, it could be questioned whether the duty of foreign nationals to provide the security for costs (cautio judicatum solvi) when initiating a lawsuit still adequately protects the defendant. In that respect, the issue of possible breach of the Serbian Constitution by Article 82 of the 1982 PIL Act arises. Consequently, depending on the response to this issue, there is a general concern about the responsibility for discrimination, which calls for urgent amendment of the relevant provision stipulated in the 1982 PIL Act.
\end{abstract}

Keywords: security for costs, PIL Act1982, discrimination, nationality, Draft PIL Act 2014.

\section{Introduction}

The security for costs (cautio judicatum solvi) is a procedural institute of private international law aimed at protecting the defendant in the cross-border civil or commercial disputes. Depending on the national legislative solutions, it could be defined as the possibility to impose the duty to the plaintiff who fails to have the relevant contact with the forum State (e.g. nationality/domicile/habitual

\footnotetext{
*sanja@prafak.ni.ac.rs

*mirko@prafak.ni.ac.rs

** This paper is a result of research conducted within the project "Harmonization of the Serbian law with the EU law", financed by the Faculty of Law, University of Niš, for period 2013-2019.
} 
residence/property) and to deposit in advance a certain sum of money or some other property which corresponds to the estimated cost of the proceeding. The rationale of this procedural institute is to provide for a swift collection of costs if the plaintiff loses the case.

At the same time, cautio judicatum demonstrates the protective impact on the defendant's right to legal protection while conditioning the plaintiff's right of access to justice. In the later case, the high amounts of security for costs could jeopardize this fundamental human right (Vuković, Kunštek, 2005: 157). Hence, the cautio judicatum solvi has changed from an easy and favoured opportunity aimed at protecting the defendant into the institute semi grata in cross-border cases. This reversal is evident from the restrictions of the security for costs introduced at the international level. Moreover, the security for costs has been prohibited in the European Union, at least in cases involving the nationals of the Member States.

In the Serbian Private International Law, the situation on this issue is rather petrified due to the fact that the relevant provisions of the 1982 PIL Act $^{1}$ have not been altered. Thus, the security for costs could be imposed on the plaintiff solely on the ground of his/her foreign nationality. Bearing this fact in mind, the recent decision of the Belgian Constitutional Court ${ }^{2}$ on the compatibility of the national rule on cautio judicatum and the constitutional prohibition of discrimination should draw the attention of the Serbian legislator. The same question could be made with regard to the 1982 PIL Act provisions on the security for costs and the Serbian Constitution. ${ }^{3}$ In dealing with this problem, the authors first analyze the international conventions regulating the security for costs (which are binding for Serbia), as well as the relevant provisions of the 1982 PIL Act. At the same time, the authors raise the question of justification of the legislative protection of the Serbian nationals de lege lata in comparison to the procedural position of aliens as stipulated in the Serbian Constitution and their right of access to justice. This issue further entails the question whether the national legislator can condition the access to justice of the foreign plaintiff solely on the ground of nationality. Even if cautio judicatum is not per se contra-

1 Zakon o rešavanju sukoba zakona sa propisima drugih zemalja, Službeni list SFRJ. Br. 43(1982), 72(1982) i Službeni list SRJ. Br. 46(1996) /The Act on Resolution of Conflict of Laws with regulations of Other Countries, Official Gazette of the SFRY. No. 43 (1982), 72(1982) and the Official Gazette of the SRY. No. 46 (1996).

2 Cour constitutionnelle, Arrêt $n^{\circ}$ 135/2018 du 11 octobre 2018, en cause: la question préjudicielle relative à l'article 851 du Code judiciaire, posée par le Tribunal de commerce de Liège, division Liège.

3 Ustav Republike Srbije, Službeni glasnik RS. Br. 98 (2006) / The Constitution of the Republic of Serbia, Official Gazette of the RS. No. 98 (2006). 
dictory to the right of access to justice, the problem of discrimination could be borne to mind. Finally, the authors make proposals for the improvement of the current legislation de lege ferenda.

\section{The Security for costs in the Serbian Private International Law}

In the Serbian Private International Law, cautio judicatum solvi is regulated in various legal sources. At the national level, the issue is tackled in Articles 82-84 of the 1982 PIL Act. At the international level, Serbia is bound by several multilateral international conventions which prescribe the exemption from the security for costs in all civil and commercial matters or only in certain matters. Besides, the issue is governed by all bilateral agreements in force in Serbia that regulate the issue of legal aid in civil matters.

\subsubsection{International treaties regulating the security for costs}

In respect of the multilateral treaties, the security for costs is in general regulated in the 1954 Hague Convention (which superseded the 1905 Hague Convention), ${ }^{4}$ and in the 1980 Hague Convention. ${ }^{5}$ Supplementary provisions on the security for costs may be found in other treaties dealing with specific PIL issues. This group of conventions includes: the 1980 Child Abduction Convention, ${ }^{6}$ the 1956 New York Convention, ${ }^{7}$ the 1999 Convention concerning International Carriage by Rail (COTIF), ${ }^{8}$ the 1973 Convention on the Contract for the International

4 Convention on Civil Procedure, Official Gazette of the FPRY - International treaties and other agreements. No. 6 (1962).

5 Convention on International Access to Justice, Official Gazette of the SFRY - International treaties. No. 4 (1998). It has replaced the Convention of 17 July 1905 on civil procedure.

6 Convention on the Civil Aspects of International Child Abduction, Official Gazette of the SFRY - International treaties. No. 7 (1991).

7 Convention on the Recovery Abroad of Maintenance, Official Gazette of the FPRY International treaties. No. 2 (1960).

8 Convention concerning International Carriage by Rail (COTIF), Uniform Rules concerning the Contract of International Carriage of Passengers by Rail (CIV), Uniform Rules Concerning the Contract of International Carriage of Goods by Rail (CIM), Official Gazette of the SFRYInternational treaties. No. 8 (1984); Protocol of 20.12.1990. for the Modification of the Convention concerning International Carriage by Rail (COTIF), Official Gazette of the SRY - International treaties. No. 3 (1993); Protocol of 3 June 1999 for the Modification of the Convention concerning International Carriage by Rail (COTIF) of 9 May 1980, Official Gazette of the RS- International treaties. No. 102 (2007). 
Carriage of Passengers and Luggage by Road (CVR) ${ }^{9}$, and the 1955 Convention on the Contract for the International Carriage of Goods by Road (CMR). ${ }^{10}$

Regarding the Hague conventions on PIL, the 1954 Hague Convention and the 1980 Hague Convention prescribe the exemption from the security for costs in all civil and commercial matters. In the 1954 Hague Convention, the exemption is conditioned cumulatively by the nationality and the domicile of the plaintiff in the Contracting States (Art. 17). The 1980 Hague Convention introduces a more flexible solution which provides that all persons having the habitual residence in the Contracting State are relieved of cautio judicatum solvi (Art. 14). Unlike the 1954 Convention, the 1980 Convention explicitly extended the exemption to the legal persons habitually resident in a Contracting State. As Möller explains, the 1980 Convention provisions on the security for costs apply only if the national legislator of a Contracting State obliges the plaintiff or intervening party to provide the deposit due to their foreign nationality or domicile abroad. Conversely, if the duty of providing cautio judicatum is of a general nature and, without exception, equally affects the forum State's nationals or the plaintiffs resident or domiciled in this State, then the application of the 1980 Convention would lead to discrimination. Moreover, it would be contrary to its objective (Möller, 1983: 282). In both Hague conventions, the exemption is supplemented through the convention system of facilitating the enforcement of order for costs. This enforcement is triggered when the plaintiff or intervening party loses the dispute which subsequently raises the question of payment of costs as well as the protection of the defendant in whose favour the decision was rendered. ${ }^{11}$

Most of other multilateral treaties regulating the plaintiff's right of access to justice in cross-border disputes on the specific issues forbid the deposit in even more generous manner. Thus, the 1956 New York Convention exempts all creditors initiating the alimony proceedings, regardless of their nationality, domicile or habitual residence (Art. 9). The same idea is followed in the 1980 Child Abduction Convention. Hence, it prevents the payment of any security, deposit or bond in the judicial or administrative proceedings falling within the scope of the Convention for the return of the wrongfully removed or retained child (Art. 22). The 1999 COTIF Convention envisages that all plaintiffs instituting the proceedings on the ground of the CIV Uniform Rules, the CIM Uniform Rules, the CUV Uniform Rules, or the CUI Uniform Rules cannot be required to pay the

9 Convention on the Contract for the International Carriage of Passengers and Luggage by Road (CVR), Official Gazette of the SFRY-International treaties. No. 8 (1977).

10 Convention on the Contract for the International Carriage of Goods by Road (CMR), Official Gazette of the FPRY - International treaties. No. 11 (1958).

11 See Arts. 18 para. 1 and 19 para. 4 of the 1954 Hague Convention, as well as Arts. 14 -17 of the 1980 Hague Convention. 
security for costs (Art. 11). However, in the matter of international carriage by road, even more stringent conditions are set. According to the 1973 CVR Convention, the plaintiff can be exempted from cautio judicatum if he is a national of the Contracting State having the residence or the place of business in one of the Contracting States (Art. 21 para. 5). The same provision is envisaged in Article 31 para. 5 of the CMR Convention. However, in applying the latter, the Serbian courts have to be cautious due to the substantive mistake made in the official translation of the CMR Convention into Serbian language. ${ }^{12}$

On the other hand, the bilateral treaties guarantee exemption from cautio judicatum solvi to the nationals of the Contracting States, ${ }^{13}$ or to the nationals who at the same time have the domicile or residence ${ }^{14}$ in one of the Contracting Sta-

12 In the translation of the CMR Convention into Serbian, provided in the Regulation on the ratification of the CMR Convention, the substantive mistake was made in terms of residence. The Regulation uses the term "stalno boravište" which alludes to habitual residence. However, the CMR Convention uses the term"residence". Therefore, the condition on "stalno boravište" is more difficult to fulfil than the condition on residence. Consequently, the translated text which is in the use in Serbia unduly narrows the conditions for exemption. For details on the difference between habitual residence and residence, see: Stanivuković, Živković, 2015:112-119.

13 Such as: Algeria (Agreement on legal assistance in civil and criminal matters between SFRY and Algiria, Official Gazette of the SFRY - International Treaties. No. 2 (1981); France (Agreement on facilitating the application of the Hague Convention on civil procedure of 1 March 1954 between SFRY and republic of France, Official Gazette of the SFRY - appendix. No. 21 (1971); Iraq (Agreement on legal and judicial cooperation between SFRY and Republic of Iraq, Official Gazette of the SFRY - International Treaties. No. 1 (1987); Italy (Convention on mutual legal assistance in civil and administrative matters between FPRY and Republic of Italy, Official Gazette of the FPRY - appendix. No. 5 (1963); Cyprus (Agreement on legal assistance in civil and criminal matters between SFRY and Republic of Cyprus, Official Gazette of the SFRY - International Treaties. No. 2 (1986); Russia (Agreement on legal assistance in civil, family and criminal matters between FPRY and SSSR, Official Gazette of the FPRYInternational Treaties. No. 5 (1963); Slovakia and Czech Republic (Agreement on regulating legal relations in civil, family and criminal matters between FPRY and SR Czechoslovakia, Official Gazette of the FPRY-appendix. No. 13 (1964); Croatia (Agreement on legal assistance in civil and criminal matters between SRY and Republic of Croatia, Official Gazette of the $S R Y$ - International Treaties. No.1 (1998).

14 Such as: Turkey (Convention on mutual relations in judicial, civil and commercial matters between the Kingdom of Yugoslavia and Republic of Turkey, Official Gazette. No.26 (1936); Austria (Agreement on mutual legal transactions between FPRY and Republic of Austria, Official Gazette of the FPRY- appendix. No. 8 (1955); Bulgaria (Agreement on mutual legal assistance between FPRY and PR Bulgaria, Official Gazette of the FPRY -International Treatiesappendix. No.1 (1957); Greece (Convention on mutual legal relations in between FPRY and Kingdom of Greece, Official Gazette of the FPRY-appendix. No. 7 (1960); Hungary (Agreement on legal assistance in civil and criminal matters between SFRY and PR Hungary (1968), amended and supplemented in 1986, Official Gazette of the SFRY - International Treaties. 
tes, or to the plaintiffs domiciled in the Contracting State or having immovable property in the forum State. ${ }^{15}$

In terms of multilateral conventions, the security for costs exemption has been gradually detached from the plaintiff's nationality. The treaties are expanding the scope of persons' exemption from the duty (thus protecting the plaintiff). Simultaneously, the provisions of the 1954 Hague Convention and the 1980 Hague Convention on the enforcement of orders for costs strive to strike a balance on the second pillar of the right of judicial protection aimed to protect the defendant who won the case. The same is true for bilateral treaties which (almost as a rule) envisage the special regime for the recognition and enforcement of orders for costs in the cases when the exemption from the cautio iudicatum was granted. ${ }^{16}$

\subsubsection{The 1982 PIL Act}

Although the international conventions in force in Serbia provide a considerable lists of States where the exemption from the security for costs is guaranteed, ${ }^{17}$ the issue still arises in the Serbian jurisprudence. ${ }^{18}$ According to the 1982 PIL

No. 3(1968), Official Gazette - International Treaties. No.1 (1987), Mongolia (Agreement on legal assistance in civil, family and criminal matters between SFRY and PR Mongolia, Official Gazette of the SFRY - International Treaties. No.7 (1982); Poland (Agreement on legal transactions in civil and criminal matters between FNRY and PR Poland, Official Gazette of the FPRY - appendix. No. 5 (1963); Romania (Agreement on legal assistance between FPRY and PR Romania, Official Gazette of the FPRY -appendix. No.8 (1961).

15 Such as: the United Kingdom (Convention between the Kingdom of Yugoslavia and the United Kingdom regulating mutual assistance in proceedings on civil and commercial matters pending before relevant judicial authorities, Official Gazette. No. 116(1937).

16 See supra ft. 14-16.

17 See supra ft. 14-16. The diplomatic reciprocity based on the multilateral treaties binding for Serbia includes 39 Contracting States of the COTIF Convention, 55 Contracting States of the CMR Convention, 8 Contracting States of the CVR Convention, 100 Contracting States of the 1980 Child Abduction Convention and 63 Contracting States of the 1956 New York Convention, as well as all the Contracting States of the 1954 Hague Convention which did not ratify the 1980 Hague Convention (26).

18 In the Serbian jurisprudence, it is not unusual to find decisions rendered upon the request for the security for costs: e.g.: Rešenje Višeg trgovinskog suda (Decision of the Higher Commercial Court) Pž. 9186/2007(1) od 22.11.2007. ; Rešenje Višeg trgovinskog suda (Decision of the Higher Commercial Court), Pž. 7628/2004 od 6.12.2004.; Rešenje Privrednog apelacionog suda (Decision of the Commercial Court of Appeal)), Pž 2616/2017 od 17.5.2017; Rešenje Višeg trgovinskog suda (Decision of the Higher Commercial Court), XVIII Pž. 13836/2005 od 7.2.2006.; Rešenje Privrednog apelacionog suda (Decision of the Commercial Court of Appeal), Pž. 10770/2011(1) od 1.8.2012. According to the data provided by the Ministry of Justice of the Republic of Serbia, in 2019, the court asked for information on the reciprocity in terms of the security for costs in 17 cases. 
Act, when a foreign citizen or stateless person who is not domiciled in Serbia institutes the court proceedings, he/she is obliged to deposit security for costs at the defendant's request. The defendant has to submit the request no later than the preparatory hearing. If the preparatory hearing has not been held, then the request has to be submitted at the first hearing on the merits before the defendant pleads to the merits, or as soon as he has learned that there are conditions for requesting the security for costs. The security for costs is usually provided in money, but the court may approve another suitable form. The plaintiff who is a foreign national could be exempted from the security on the ground of the reciprocity which could be diplomatic or factual (Art. 82 of the PIL Act 1982). However, in some cases, the fulfilment of the reciprocity condition is not easy to determine. From the viewpoint of the legal system (such as Serbian) insisting on the nationality alone, it may be difficult to appraise whether the factual reciprocity has been established if the plaintiff's national State does not attach the exemption to the nationality but rather to the territorial connecting factor (domicile, habitual residence, residence or property).

Besides the general rule regarding the foreign nationality, the 1982 PIL Act also prescribes that cautio iudicatum is excluded if the plaintiff enjoys the right of asylum in Serbia. Further on, the security cannot be requested in some types of disputes as expressly listed in the 1982 PIL Act. It includes the claim related to the plaintiff's receivable arising from his contract of employment in Serbia. The exemption applies also in marital disputes, or paternity or maternity disputes, or in case of maintenance obligations. Finally, cautio cannot be requested if the case involves an action upon a bill of exchange or cheque, or a counterclaim or issuance of a payment order (Art. 83 of the PIL Act 1982).

\section{The justification of the 1982 PIL Act's solutions in terms of the Serbian Constitution}

Before the discussion on the (non)discriminatory nature of the conditions set in the 1982 PIL Act, it should be noted that the security for costs, as a procedural institute, does not per se imply the denial of justice (Palombino, 2018: 70). As it was stressed, in cross-border cases, the ratio of the protection of the defendant who even does not have to be a national of the forum State (Vuković, Kunštek, 2005: 155). The enforcement of the order for cost could depend on its recognition and enforcement in the State where the plaintiff has assets. In order to avoid this cumbersome situation, the security for costs could be justified. Although the institute is not contradictory to the right of access to justice, the conditions upon which it could be imposed have to be in line with the non-discrimination principle. 
The prohibition of discrimination is introduced at the international level and in Serbian law. With regard to the international treaties binding for Serbia, the discrimination based on the nationality which may interfere with the right of access to justice or the equality before the law is envisaged in the UN Charter, ${ }^{19}$ the Universal Declaration of Human Rights, ${ }^{20}$ the International Covenant on Civil and Political Rights, ${ }^{21}$ and the European Convention for the Protection of Human Rights and Fundamental Freedoms, ${ }^{22}$ including Protocol No. 12 to the Convention. ${ }^{23}$

At the national level, the Serbian Constitution introduces the prohibition of the direct or indirect discrimination based on the nationality, among other grounds. ${ }^{24}$ Moreover, the Constitution guarantees to everybody the right of access to independent, impartial court as well as the right of a fair trial, including the judicial protection of the human or minority rights envisaged in the Constitution..$^{25}$ The fact that the non-discriminatory principle is set in the Constitution allows for the direct application of the rights guaranteed in the Constitution. The human rights, including the right of access to justice, guaranteed by the rules of international law and confirmed by international treaties and statutory provisions, apply directly (Tasić, 2016: 134). Moreover, the non-discriminatory

19 Art. 55 para. 1(c) of the Charter calls for the universal respect of human rights and fundamental freedoms.

20 Art. 2 of the Universal Declaration envisaged that "everyone is entitled to all the rights and freedoms set forth in this Declaration, without distinction of any kind, such as race, colour, sex, language, religion, political or other opinion, national or social origin, property, birth or other status." Moreover, Art. 7 UDHR states that "all are equal before the law and are entitled without any discrimination to equal protection of the law. All are entitled to equal protection against any discrimination in violation of this Declaration and against any incitement to such discrimination" (emphasized by the authors).

21 Art. 26 of the 1966 Covenant prescribes that "All persons are equal before the law and are entitled without any discrimination to the equal protection of the law. In this respect, the law shall prohibit any discrimination and guarantee to all persons equal and effective protection against discrimination on any ground such as race, colour, sex, language, religion, political or other opinion, national or social origin, property, birth or other status" (emphasized by the authors).

22 Art. 14 of the ECHR specifies that "the rights and freedoms set in the Convention shall be secured without discrimination on any ground such as ... national or social origin..."

23 Art. 1 of the Protocol No. 12 introduces the general prohibition of discrimination, complementing the provision of Art. 14 of the ECHR which entails the prohibition in terms of the right guaranteed by the Convention.

24 Art. 21 of the Constitution of the Republic of Serbia, Official Gazette of the RS. No. 98 (2006).

25 Arts. 22 and 32 para. 1 of the Constitution. 
principle is part of the Serbian public policy in Private International Law. ${ }^{26}$ The Anti-Discrimination $\mathrm{Act}^{27}$ envisages the equal right to legal protection, irrespective of personal properties. ${ }^{28}$ In the civil court proceedings, the courts cannot refuse to decide on the claim if it has jurisdiction, while the parties enjoy the right of legal, equal and fair protection of their rights (Art. 2 of the Contentious Proceedings Act).$^{29}$ This duty equally refers to the plaintiff of Serbian or foreign nationality (Stanivuković, Živković, 2015: 150). However, the distinction has been made between the right of access to justice as a universal right and the right to file a claim which does not necessarily calls for the equality between the forum State's nationals and aliens (Jakšić, 2016: 262).

In that respect, one could question the justification of imposing the duty to deposit security for costs solely on the ground of foreign nationality which is envisaged in the 1982 PIL Act. As already noted, the main purpose of cautio iudicatum is to prevent the situation when the plaintiff does not have sufficient property in the forum State, which raises the concerns whether the order for costs against the plaintiff could be enforced abroad (Palambino, 2018: 70). The rules of the 1982 PIL Act preclude the court from releasing the plaintiff from the duty to deposit the security without breaking the law, even if he/she has the assets in Serbia. Although absurd, this outcome is inevitable. ${ }^{30}$ The court can decide on the exemption only if the requirement of reciprocity is fulfilled. Still, even when the international treaty has to be applied exempting the plaintiff of cautio judicatum, the courts prefer to order the security for costs. ${ }^{31}$

Since the discrimination entails the unjustified different position of the persons in the same or similar situation, ${ }^{32}$ it should be borne to mind that the relevant provision of the 1982 PIL Act produces precisely this effect. Unlike foreign plaintiffs instituting a contentious proceeding in Serbia, the plaintiffs who are Serbian nationals living abroad would be in a more favourable position. Regardless of whether the plaintiff from this category has assets in Serbia, he/

26 Art. 4 of the 1982 PIL Act envisages a narrow definition of the Serbian public policy which includes the constitutional principles.

27 The Anti-Discrimination Act, Official Gazette RS. No. 22(2009).

28 Art. 4 of the Anti-Discrimination Act.

29 The Contentious Proceedings Act, Official Gazette RS No. 2 (2011), 49(2013), 74 (2013), 55 (2014), (87) 2018.

30 For the critique, see: Jakšić, 2016: 266; Stanivuković, Živković, 2015: 154 (in the context of the plaintiff's domicile in Serbia).

31 Rešenje Višeg trgovinskog suda (Decision of the Higher Commercial Court), Pž. 11892/2005 od 07.02.2006. and Rešenje Višeg privrednog suda (Decision of the Higher Commercial Court), Pž. 1032/2001 od 22.02.2001. See Jakšić, 2016: 266, ft. 896.

32 Art. 2 para. 1 (1) of the Anti-Dicrimination Act. 
she will not be obliged to deposit any security. Consequently, cautio judicatum becomes an inefficient way to protect the defendant who won the case due to the fact that the enforcement of the order for costs abroad is equally uncertain, as it would be if the plaintiff were an alien. Moreover, the plaintiffs possessing another nationality besides the Serbian one would be also exempt from the duty to pay the security for costs due to the principle of exclusiveness of the nationality of the forum State (the PIL Act, 1982, Art. 11 para. 1). In the age of mass migration, it may happen that the plaintiffs who are Serbian nationals do not have any assets in Serbia because they moved and settled abroad. At the same time, the plaintiff could be born abroad, living his/her all life abroad without any contacts with Serbia, but still having Serbian nationality due to the ius sanguinis principle. ${ }^{33}$ In these circumstances, the plaintiff actually does not have to have any substantial link with Serbia except for the Serbian nationality. In terms of cautio judicatum solvi, even this "paper-based nationality" could serve as a ground for an absolution from cautio judicatum. ${ }^{34}$ This unequal treatment constitutes at least indirect discrimination. ${ }^{35}$

When assessing whether the effects of such provision are disproportionate, the standpoint of the ECtHR on this issue has to be taken into consideration. As it was previously mentioned, the ECHR envisages the right to a fair trial (Article 6) which comprise the right of access to justice. Although crucial, this right is not absolute. Thus, it could be limited by the national legislation as long as these restrictions do not produce a negative effect on the essence of this right. Consequently, the State enjoys a margin of appreciation in this respect, but the ECtHR has the final word in evaluating whether there is a compliance with the requirements of the Convention..$^{36}$ The limitation could be of financial nature, which confirms that the security for costs does not per se lead to the denial of justice. ${ }^{37}$ In the case Mogielnicki v. Poland, ${ }^{38}$ the European Court found that:

33 The ius sanguinis principle is one of the grounds for acquiring Serbian nationality according to Art. 7 of the Nationality Act of the Republic of Serbia, Official Gazette of the RS. No. 135 (2004), 90 (2007) and 24 (2018).

34 The problem of the so called "paper-based" Serbian nationality is not the exclusiveness of the security for costs but rather the common issue of the 1982 PIL Act. See in detail: Marjanović, 2013: 404.

35 See CJEU explanation of indirect discrimination in Case 152/73 Sotgiu v. Deutsche Bundespost, Judgment of 12 February 1974. (Etinski, 2015: 42.)

36 ECtHR judgments in Kreuz v. Poland of 19 June 2001, and VM. v. Bulgaria, 45723/99 of 8 June 2006.

37 On the interpretation of the denial of justice in the cross-border cases, see Palombino, 2018: 62-64 and the literature referred therein.

38 The ECtHR judgment is available in French: Affaire Mogielnicki c. Pologne (Requête no 42689/09), Arrêt du 15 septembre 2015. 
"Dans l'ensemble de ces affaires, la Cour a toutefois vérifié si les limitations appliquées n'avaient pas restreint l'accès ouvert au justiciable d'une manière ou à un point tels que le droit s'en était trouvé atteint dans sa substance même." (Affaire Mogielnicki c. Pologne (Requête no 42689/09), Arrêt du 15 septembre 2015, para. 49)

In terms of cautio judicatum, the ECtHR has found that its nature serves the legitimate aim, which is the prevention of the defendant from being confronted with the impossibility of recovering the costs of the proceeding. ${ }^{39}$ Nevertheless, it does not mean that any condition set in order to impose the security for costs could be acceptable.

In that regard, the recent decision of the Belgian Constitutional Court may serve as a guiding principle for the amendments of 1982 PIL Act's rule on cautio judicatum. In 2015, the Commercial Court of Liège (le Tribunal de commerce de Liège) was seized in the litigation between the "Groupinvest-Liège" partners. By judgment of 6 October 2017 in the matter of G.J. et M.B. contre la SNC "GroupinvestLiège" en liquidation et autres, ${ }^{40}$ the Commercial Court of Liège submitted a request for a preliminary ruling to the Constitutional Court ${ }^{41}$ because the defendants had raised an exception based on Article 851 of the Belgian Code judiciaire. According to Article 851 of the Belgian Code judiciaire, all foreign plaintiffs or intervening party have to deposit security for costs upon the request of the Belgian national. In the "Groupinvest-Liège" case, two plaintiffs were domiciled in Ecuador, and they did not have any property in Belgium anymore. The Commercial Court of Liège stated that the purpose of the cautio judicatum solvi is to protect the Belgian nationals against unfounded trial. This provision is based on the presumption that the foreign plaintiff having no property in Belgium could not pay the costs of the proceeding. ${ }^{42}$

The Belgian Constitutional Court noted that Article 851 of the Code judiciaire does not refer to the hypothesis of a Belgian claimant (a legal person or natural

39 The ECtHR Judgment in the case Tolstoy Moloslavsky v. United Kingdom (Application no. 18139/91) of 13 July1995, paragraph 61.

40 G.J. et M.B. contre la SNC "Groupinvest-Liège" en liquidation et autres. Arrêt n 135/2018 du 11 octobre 2018, p. 14.

41 The question was as follows: "Does Article 851 of the Code judiciare violate the constitutional principles of equality and non-discrimination if it has the effect of treating differently a Belgian defendant as opposed to a foreign plaintiff and a Belgian defendant as opposed to a Belgian plaintiff living or established abroad, who has no assets in Belgium, so that the Belgian defendant has no guarantee that this plaintiff will be able to face a decision rendered against him?" G.J. et M.B. contre la SNC "Groupinvest-Liège en liquidation et autres", Arrêt n 135/2018 du 11 octobre 2018, p. 2.

42 G.J. et M.B. contre la SNC “Groupinvest-Liège...", Arrêt n 135/2018 du 11 octobre 2018, p. 7. 
person), who would be domiciled or seated in a third State without having any assets in Belgium. ${ }^{43}$ The Constitutional Court found that the Belgian defendant, who was brought before a court by a person having no assets in Belgium and seated abroad, would be exposed to the same risks even if the plaintiff were Belgian. ${ }^{44}$ Therefore, the Court stated that the provision on cautio judicatum in Code judiciaire deals differently with the plaintiff's nationality, without taking into account the plaintiff's solvency situation in Belgium. ${ }^{45} \mathrm{As}$ a result, the Constitutional Court rendered the decision that this provision breaches the constitutional prohibition of discrimination and the principle of equality of the Belgian nationals before the law. ${ }^{46}$

The resemblance between Article 851 of the Belgian Code judiciare and Article 82 of the Serbian PIL Act is striking. In the event when the case involves the plaintiff of a foreign nationality and the intervening party of Serbian nationality, pursuant to Art. 82 of the 1982 PIL Act, the alien would be obliged to deposit the security while the Serbian national would be automatically exempted from this duty even if he/she has no assets in Serbia. However, the main purpose of the cautio iudicatum is not to punish the alien who initiated the lawsuit but rather to establish the certainty of the prospective enforcement of the order for costs. If the plaintiff is a national of a forum State but lives abroad and has no assets in the forum State, then the defendant is left unprotected. As a result, cautio iudicatum becomes meaningless. Even more, the different treatment is discriminatory on the ground of nationality since it produces negative effect on the essence of the right of access to justice. Hence, the proceeding on the review of the constitutionality of Article 82 of the 1982 PIL Act could be initiated before the Serbian Constitutional Court. ${ }^{47}$

\section{Conclusion}

As we have seen, the provision of Article 82 of the 1982 PIL Act could not be left in force without breaching the principle of non-discrimination, as envisaged

43 Arrêt $n^{\circ} 135 / 2018$ du 11 octobre 2018, p. 8.

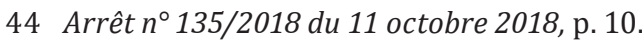

45 Arrêt $^{\circ} 135 / 2018$ du 11 octobre 2018, p. 10.

46 Arrêt n $^{\circ}$ 135/2018 du 11 octobre 2018, p. 10. Arts. 10 and 11 of the Belgian Constitution. The Constitutional Court imposed the duty to enact a new legislation (by 31 August 2019) to end the discrimination. The abrogation of the relevant provision on cautio judicatum was proposed even before the Constitutional Court judgment was rendered. Proposition de loi abrogeant les articles 851 et 852 du Code judiciaire instituant l'exception de la caution de l'étranger demandeur (déposée par Z. Genot et T. Van der Straeten), 2010.

47 Art. 50 of the Constitutional Court Act, Official Gazette of the RS. No. 109 (2007), 99 (2011), 18 (2013)...40(2015). No. 109 (2007), 99 (2011), 18 (2013)...40(2015). 
in Article 21 of the Serbian Constitution and other national and international legal acts. The arguments correspond perfectly to those analysed in the decision of the Belgian Constitutional Court. Hence, it raises another dilemma: what solution should replace the current one? In that regard, we should bear in mind the rationale of the security for costs as well as the rules adopted in the comparative Private International Law. In terms of the latter, the 1980 Hague Convention has had an impact on the legislation of its Contracting States. The cautio judicatum is still envisaged in the legislation of nine Contracting States, ${ }^{48}$ while eleven States do not request the security for costs. ${ }^{49}$ In regard of the 17 non-Contracting States which took part in a survey carried out by the Hague Conference on Private International Law, cautio judicatum is still very much alive as a procedural institute, considering that only five States do not impose this duty. ${ }^{50}$ However, nationality is not often used as a condition. Most of the States envisage some other criterion (habitual residence, domicile, seat, residence or property located abroad). ${ }^{51}$

When it comes to the States established after the dissolution of the SFRY, most of them have kept the same provision as the 1982 PIL Act in spite of fact that this Act is still applied only in Serbia and Bosnia and Herzegovina. The Republic of North Macedonia made a slight change in comparison with the 1982 PIL Act, envisaging the same conditions but excluding the legal persons (Deskoski, 2008: 455). ${ }^{52}$ In the new Croatian PIL Act, the security for costs is imposed on the plaintiff who is not Croatian or a national of other EU State, or the State that is Party to another international treaty abolishing the security for costs. If this plaintiff has a domicile or seat in a non-EU State or in a non-Contracting State, he/she is obliged to provide security upon the defendant's request (Art. 61 para.

48 These states are: Bosnia and Herzegovina, Croatia, Cyprus, Czech Republic, Estonia, Luxembourg, Serbia, Slovakia, and Sweden (Permanent Bureau, 2009: 7).

49 These states are: Brazil, Bulgaria, Finland, France, Lithuania, Malta, the Netherlands, Poland, Romania, Slovenia, and Spain (Permanent Bureau, 2009: 7).

50 These states are: Australia, El Salvador, Portugal, Sri Lanka, and Ukraine. On the other hand, this duty is still imposed in the legislation of Argentina, Belgium, Canada, Denmark, Germany, Hungary, Japan, Malaysia, Monaco, Norway, Russia, and the USA. The survey was taken by the Permanent Bureau of the Hague Conference on Private International Law (Permanent Bureau, 2014: 14-19).

51 It includes Cyprus, Czech Republic, Estonia, Slovakia, and Switzerland. (Permanent Bureau, 2014: 26-27.)

52 Законот за меѓународно приватно право, Службен весник на Република Македонија. Бр. 87 (2007). Закон за изменување и дополнување, Службен весник на РМ. Бр.156 (2010) (Private International Law Act, Official Gazette. No. 87 (2007) with amendments of 2010 Official Gazette. No. 156 (2010). 
1, the Croatian PIL Act 2017).$^{53}$ The Montenegrin PIL Act and the Slovenian PIL Act rely completely on the 1982 PIL Act (Art. 137, the Montenegrin PIL Act 2014; Art. 90, the Slovenian PIL Act 1999).$^{54}$ In all other States, except Croatia, the legislation on the security for costs is discriminatory as well. ${ }^{55}$

In respect of the possible solution de lege ferenda, the 2014 Draft PIL Act of the Republic of Serbia ${ }^{56}$ brings a significantly different rule by introducing the habitual residence of the plaintiff in Serbia as a criterion for exempting him/her from the security (Art. 31). By providing the habitual residence of the plaintiff as a criterion, the Draft PIL Act places the foreign and Serbian nationals on equal footing. As a result, every plaintiff who does not have habitual residence in Serbia would be obliged to pay the security for costs upon the defendant's request regardless of his/her nationality. In addition, the Draft PIL Act corrects the error made in Article 82 of the 1982 PIL Act in respect of stateless persons. Instead of habitual residence, the current Act prescribes domicile ${ }^{57}$, in case of breach of the Convention relating to the Status of Stateless Persons (Art. 16 paras. 2 and 3 of the Convention on the Status of Stateless Persons, 1954). ${ }^{58}$ Further on, in case of refugees, the 2014 Draft PIL Act makes a referral to the Convention relating to the Status of Refugees with its Protocol. ${ }^{59}$

Taking into consideration the other territorial factors which could be stipulated as a condition for the exemption from cautio judicatum, domicile would not be as adequate as habitual residence. The requirements which have to be met for a foreign national to establish his/her domicile in Serbia are very strict. Pursuant

53 Zakon o međunarodnom privatnom pravu, Narodne novine. br. 101 (2017) / Private International Law Act, Official Gazette of Croatia. No. 101 (2017).

54 Zakon o mednarodnem zasebnem pravu in postopku - ZMZPP (The PIL Act), Uradni list RS. Št. 56 (1999); Služben vesnik na Republika Makedonija. No. 87 (2007). Službeni list CG. Br. 1 (2014).

55 Cautio judicatum solvi violates Articles 14, 15, 22 and 23 of the Slovenian Constitution; Articles 17, 19 and 24 of the Montenegrin Constitution; Art. 2(4) of the Constitution of Bosnia and Herzegovina; Art. 29 of the Constitution of North Macedonia.

56 Nacrt novog Zakona o međunarodnom privatnom pravu Republike Srbije, jun 2014 (The Draft on the new Private International Law Act of the Republic of Serbia, June 2014). Retrieved 21.11.2019. from https://www.mpravde.gov.rs/obavestenje/6274/konacna.

57 The PIL Act, 1982, Art. 82 para. 1.

58 Convention relating to the Status of Stateless Persons, Official Gazette of the FPRYsupplement No. 9 (1959).

59 Convention relating to the Status of Refugees, Official Gazette of the FPRY); Official Gazette of the SFRY-appendix. International Treaties, No. 15 (1967)/ Protocol on the Status of Refugees, Official Gazette of the SFRY -supplement. No. 7 (1960). 
to the new Foreigners Act, ${ }^{60}$ the Ministry of Internal Affairs can grant a domicile permit to a foreigner: a) who has been living continuously in Serbia for more than five years on the basis of a temporary stay permit; or b) who has been married for at least three years to a national of the Republic of Serbia or to a foreigner who has a domicile permit; or c) who is a minor, temporarily staying in Serbia, if one of his/her parents is a national of the Republic of Serbia or a foreigner who has a domicile permit, with the consent of the other parent; or d) who has his origins in Serbia (Arts. 67 and 68 of the Foreigners Act 2018). Exceptionally, a domicile permit may also be granted to foreigners whose temporary stay has been permitted, but only if it may be justified by humanitarian reasons, or if the interests of the Republic of Serbia prevail (Art. 68 para. 1(4) of the Foreigners Act 2018). Hence, some foreign nationals do not fulfil the conditions despite the fact that they actually have been living in Serbia for many years (Marjanović, 2016: 99-101). On the other hand, Serbian nationals living abroad could keep their ID cards proving their domicile in Serbia, which would allow for the exemption from the security for costs. ${ }^{61}$ If the new provision on the security for costs would rely on the domicile, it could still make the discrimination possible, thus causing the breach of the Constitution once again.

The other possibility is to condition the exemption from the security for costs with possession of property located in Serbia, whose amount could cover the costs of the proceeding. This criterion could be envisaged as an alternative to the habitual residence. The habitual residence presupposes that the person has assets in the State where he/she resides ${ }^{62}$ since it is the State in which he/she has the centre of interests, taking into consideration all the circumstances of personal or business nature which indicate more durable connections with that State or the intention to establish such connections. ${ }^{63}$ Moreover, the habitual residence could include legal persons as well, ${ }^{64}$ who are also obliged to deposit the security for costs as a result of the interpretation of the courts. ${ }^{65}$ Despite the fact that it is hard to anticipate the situation in which the habitual residence could

60 The Foreigners Act, Official Gazette of the RS, No. 24 (2018) and 34 (2019).

61 The Act on the domicile and residence of the RS citizens envisages the possibility declare the domicile as passive when a Serbian national does not live at the address stated in the ID card, but this solution has its own flaws. See Art. 18 of the Act on Domicile and Residence of RS Citizens, Official Gazette RS, No. 87 (2011).

62 On the habitual residence, see Limante, 2018: 160-182. For the general overview, see especially Richez-Pons, 2004: 409-468.

63 In that sense, see Art. 6 of the 2014 Draft PIL Act.

64 See Art. 7 of the 2014 Draft PIL Act.

65 Rešenje Višeg trgovinskog suda (Decision of the High Commercial Court), Pž. 8563/2003 od 22.12.2003. 
exist without having property located in that State, the property alone could be acquired irrespective of the habitual residence. Thus, the plaintiff could have assets in Serbia while he/she habitually resides elsewhere. The property criterion could serve as an alternative to the habitual residence in the prospective provision on cautio judicatum. Although the inclusion of the property criterion could be further discussed in the process of amending Article 82 of the PIL Act, the prolonged breach of the Constitution and the principle of non-discrimination by keeping the status quo certainly cannot be supported. Otherwise, the State can be brought to the ECtHR for breaching the prohibition of discrimination.

\section{References}

Deskoski, T. (2008). The New Macedonian Private International Law Act of 2007, Yearbook of Private International Law. 10. 441-458.

Etinski, R. (2015). Concept of indirect discrimination under Article 14 of the European Convention on Human Rights. Zbornik radova Pravnog fakulteta $u$ Nišu. 70 (2015). 41-58.

Limante, A. (2018). Establishing habitual residence of adults under the Brussels IIa regulation: best practices from national case-law. Journal of Private International Law. 14(2018). 160-181.

Jakšić, A. (2016). Međunarodno građansko procesno pravo (International Civil Pricedural Law). Beograd.

Marjanović, S. (2016). Personal name in Serbian Family law and Private International Law de lege lata and de lege ferenda. In: Živković, M. (Ed.): 4th Balkan Conference "Personal Name in Internal Law and Private International Law": Niš: University of Niš, Faculty of Law. 91-112.

Marjanović, S. (2013). Međunarodna nadležnost za sporove o izdržavanju u međunarodnom privatnom pravu Srbije de lege lata i de lege ferenda (International juridiction for maintenance disputes in the Serbian Private International Law de lege lata and d lege ferenda). Zbornik radova Pravnog fakulteta u Nišu, 65.399-418.

Möller, G. (1983). Explanatory Report on the 1980 Hague Access to Justice Convention. U Actes et documents de la Quatorzième session (Tome IV, Entraide judiciaire). La Haye. 235-290

Palombino, F. M. (2018). Fair and Equitable Treatment and the Fabric of General Principles. T.M.C. Asser Press: The Hague. 
Permanent Bureau (2009). Summary of responses to the questionnaire of September 2008 relating to the access to Justice Convention, with analytical comments (summary and analysis document). 2009. Retrieved 21.11.2019. from https:// assets.hcch.net/upload/wop/2008pd15e.pdf

Permanent Bureau (2014). Synopsis of responses to the questionnaire of November 2013 relating to the Hague Convention of 25 October 1980 on International Access to Justice (Access to Justice Convention), revised version of July 2014. Retrieved 21.11.2019. from https://assets.hcch.net/docs/6795eb0b-3eed-47cf-84c313e257c85a98.pdf

Richez-Pons, A. (2005). La notion „residence“, Le nouveau droit communautaire du divorce et de la responsabilité parentale (PhD thesis). Dalloz.

Stanivuković, M, Živković, M. (2015). Međunarodno privatno pravo: opšti deo (International Private Law: General Part). Beograd.

Tasić, A. (2016). Postupak u parnicama za zaštitu od diskriminacije (Civil Procedure in Anti-discrimination Lawsuits) (PhD thesis). Retrieved 21.11.2019. from http://nardus.mpn.gov.rs/handle/123456789/9542?locale-attribute=sr_RS

Vuković, Đ., Kunštek, E. (2005). Međunarodno građansko postupovno pravo (International Civil Procedural Law).Zagreb.

International treaties and legislation

Charter of Fundamental Rights of the European Union. 2000/C 364/01. Official Journal of the European Communities, 18.12.2000; https://www.europarl.europa. eu/charter/pdf/text_en.pdf

Charter of the United Nations (1945), UN website: https://www.un.org/en/ charter-united-nations/

European Convention for the Protection of Human Rights and Fundamental Freedoms, Službeni glasnik RS-Međunarodni ugovori br.12 (2010)/Official Gazette $R S$-International treaties, No.12 (2010).

International Covenant on Civil and Political Rights (1966), UN Treaty series 1976. https://reaties.un.org/doc/publication/unts/volume\%20999/volume999-i-14668-english.pdf

Universal Declaration of Human Rights (UDHR, 1948), UN website: https://www. un.org/en/universal-declaration-human-rights/

Konvencija o građanskom postupku, Službeni list FNRJ - Međunarodni ugovori i drugi sporazumi. Br. 6 (1962)/Convention on Civil Procedure, Official Gazette of the FPRY - International treaties and other agreements. No. 6 (1962). 
Konvencija o olakšanju međunarodnog pristupa sudovima, Službeni list SFRJ Međunarodni ugovori. Br. 4 (1988)/Convention on International Access to Justice, Official Gazette of the SFRY - International treaties. No. 4 (1998).

Konvencija o građanskopravnim aspektima međunarodne otmice dece, Službeni list SFRJ - Međunarodni ugovori. Br. 7 (1991)/ Convention on the Civil Aspects of International Child Abduction, Official Gazette of the SFRY - International treaties. No. 7 (1991).

Konvencija o ostvarivanju alimentacionih zahteva u inostranstvu, Službeni list FNRJ - Međunarodni ugovori i drugi sporazumi. Br. 2 (1960)/ Convention on the Recovery Abroad of Maintenance, Official Gazette of the FPRY - International treaties. No. 2 (1960).

Konvencija o međunarodnim prevozima železnicom (COTIF), Jednoobrazna pravila o ugovoru o međunarodnom železničkom prevozu putnika i prtljaga (CIV), Jednoobrazna pravila o ugovoru o međunarodnom prevozu robe železnicama (CIM) / Convention concerning International Carriage by Rail (COTIF), Uniform Rules concerning the Contract of International Carriage of Passengers by Rail (CIV), Uniform Rules Concerning the Contract of International Carriage of Goods by Rail (CIM), Službeni list SFRJ - Međunarodni ugovori. Br. 8 (1984)/

Konvencija o ugovoru o međunarodnom drumskom prevozu putnika i prtljaga (CVR) / Convention on the Contract for the International Carriage of Passengers and Luggage by Road (CVR), Službeni list SFRJ - Međunarodni ugovori. Br. 8 (1977)

Konvencija o ugovoru za međunarodni prevoz robe drumom (CMR) i Protokol uz Konvenciju/ Convention on the Contract for the International Carriage of Goods by Road (CMR), Službeni list FNRJ - Međunarodni ugovori i drugi sporazumi. Br. 11 (1958)

Konvencija o uzajamnoj pravnoj pomoći u građanskim i upravnim stvarima između FNRJ i Italijanske Republike/Convention on mutual legal assistance in civil and administrative matters between FPRY and Republic of Italy, Službeni list FNRJ-dodatak. Br. 5 (1963).

Konvencija između Kraljevine Jugoslavije i Republike Turske o uzajamnim odnosima u predmetima sudskim, građanskim i trgovačkim/ Convention on mutual relations in judicial, civil and commercial matters between the Kingdom of Yugoslavia and Republic of Turkey, Službene novine. Br.26 (1936).

Konvencija između Kraljevine Jugoslavije i Velike Britanije o uređenju međusobne pomoći u vođenju postupka u građanskim i trgovačkim stvarima koje su u tečaju ili koje mogu biti u tečaju pred odnosnim sudskim vlastima/Convention between the Kingdom of Yugoslavia and the United Kingdom regulating mutu- 
al assistance in proceedings on civil and commercial matters pending before relevant judicial authorities, Službene novine. Br. 116(1937).

Konvencija o uzajamnim pravnim odnosima između FNRJ i Kraljevine Grčke/ Convention on mutual legal relations in between FNRY and Kingdom of Greece, Službeni list FPRY-dodatak.Br.7 (1960).

Konvencija o pravnom položaju lica bez državljanstva, Službeni list FNRJ -dodatak. Međunarodni ugovori. Br. 9 (1959). /Convention relating to the Status of Stateless Persons, Official Gazette of the FPRY - supplement. No. 9 (1959).

Konvencija o statusu izbeglica, Službeni list FNRJ- dodatak. Međunarodni ugovori Br.7 (1960)/ Convention relating to the Status of Refugees, Official Gazette of the FPRY); and Protokol o statusu izbeglica, Službeni list SFRJ-dodatak. Međunarodni ugovori, br. 15 (1967)/ Protocol on the Status of Refugees, Official Gazette of the SFRY - supplement. No. 7 (1960).

Proposition de loi abrogeant les articles 851 et 852 du Code judiciaire instituant l'exception de la caution de l'étranger demandeur (déposée par Z. Genot et T. Van der Straeten), 2010; Retrieved 21.11.2019. from https://www.lachambre. be/FLWB/PDF/52/2561/52K2561001.pdf

Protocol No. 12 to the European Convention for the Protection of Human Rights and Fundamental Freedoms (2000), https://www.echr.coe.int/Documents/ Library_Collection_P12_ETS177E_ENG.pdf

Protokol o izmenama Konvencije o međunarodnim prevozima železnicim, Službeni list SRJ - Međunarodni ugovori. Br. 3(1993)/Protocol of 20.12.1990. for the Modification of the Convention concerning International Carriage by Rail (COTIF), Official Gazette of the SRY - International treaties. No. 3 (1993)

Protokol od 3.6.1999. o izmenama Konvencije o međunarodnim železničkim prevozima od 9.5.1980. Službeni glasnik RS- Međunarodni ugovori. Br. 102 (2007) /Protocol of 3 June 1999 for the Modification of the Convention concerning International Carriage by Rail (COTIF) of 9 May 1980, Official Gazette of the RSInternational treaties. No. 102 (2007).

Sporazum o olakšanju primene Haške konvencije o građanskom postupku od 1. marta 1954. između SFR Jugoslavije i Francuske Republike/Agreement on facilitating the application of the Hague Convention on civil procedure of 1 March 1954 between SFRY and republic of France, Službeni list SFRJ- dodatak. Br. 21 (1971).

Ugovor o pravnoj pomoći u građanskim i krivičnim stvarima između SFR Jugoslavije i DNR Alžir/Agreement on legal assistance in civil and criminal matters between SFRY and Algeria, Službeni list SFRJ - Međunarodni ugovori. No. 2 (1981). 
Ugovor o pravnoj i sudskoj saradnji između SFR Jugoslavije i Republike Iraka/ Agreement on legal and judicial cooperation between SFRY and Republic of Iraq, Službeni list SFRJ - Međunarodni ugovori. No. 1 (1987).

Ugovor o pravnoj pomoći u građanskim i krivičnim stvarima između SFRJ i Republike Kipar/ Agreement on legal assistance in civil and criminal matters between SFRY and Republic of Cyprus, Službeni list SFRJ - Međunarodni ugovori. Br. 2 (1986).

Ugovor o pravnoj pomoći u građanskim, porodičnim i krivičnim stvarima između FNRJ i SSSR-a/ Agreement on legal assistance in civil, family and criminal matters between FPRY and SSSR, Službeni list SFRJ. Br. 5 (1963).

Ugovor o regulisanju pravnih odnosa u građanskim, porodičnim i krivičnim stvarima između SFRJ i SR Čehoslovačke Agreement on regulating legal relations in civil, family and criminal matters between FPRY and SR Czechoslovakia, Službeni list SFRJ- dodatak. Br. 13 (1964).

Ugovor između SRJ i Republike Hrvatske o pravnoj pomoći u građanskim i krivičnim stvarima/ Agreement on legal assistance in civil and criminal matters between SRY and Republic of Croatia, Službeni list SRJ - Međunarodni ugovori. Br. 1 (1998).

Ugovor o uzajamnom pravnom saobraćaju između FNRJ i Republike Austrije/ Agreement on mutual legal transactions between FPRY and Republic of Austria, Službeni list FNRJ-dodatak.Br.8(1955).

Ugovor o uzajamnoj pravnoj pomoći između FNRJ i NR Bugarske/Agreement on mutual legal assistance between FPRY and PR Bulgaria, Službeni list FNRJdodatak. Br. 1 (1957).

Ugovor o pravnoj pomoći u građanskim i krivičnim stvarima između SFRJ i NR Mađarske (1968) sa izmenama i dopunama (1986)/ Agreement on legal assistance in civil and criminal matters between SFRY and PR Hungary (1968), amended and supplemented in 1986, Službeni list SFRJ-dodatak. Br. 3(1968), Službeni list SFRJ- Međunarodni ugovori. Br.1 (1987).

Ugovor o pružanju pravne pomoći u građanskim, porodičnim i krivičnim stvarima između SFRJ i Mongolske Narodne Republike/Agreement on legal assistance in civil, family and criminal matters between SFRY and PR Mongolia, Službeni list SFRJ-Međunarodni ugovori. Br.7 (1982).

Ugovor o pravnom saobraćaju u građanskim i krivičnim stvarima između FNRJ i NR Poljske/ Agreement on legal transactions in civil and criminal matters between FPRY and PR Poland, Službeni list FNRJ-dodatak. Br. 5 (1963). 
Ugovor o pravnoj pomoći između FNRJ i Rumunske Narodne Republike/Agreement on legal assistance between FNRY and PR Romania, Službeni list FNRJdodatak. Br.8 (1961).

National legislation

Belgian Constitutional Court, Arrêt n 135/2018 du 11 octobre 2018, en cause: la question préjudicielle relative à l'article 851 du Code judiciaire, posée par le Tribunal de commerce de Liège, division Liège. Published in Revue belge de droit international privé, 4/2018.

Ustava Republike Slovenije (Constitution of the Republic of Slovenia), Uradni list RS, št. 33/91-I, 42/97, UZS68, 66/00, UZ80, 24/03, UZ3a, 47, 68, 69/04, UZ14, 69/04, UZ43, 69/04, UZ50, 68/06 , UZ121,140,143, 47/13, UZ148, 47/13, UZ90,97,99 in 75/16, UZ70a.

Ustav Crne Gore (Constitution of the Republic of Montenegro), Službeni list CG. Br. 1(2007) i 38(2013) - Amandmani I-XVI)

Ustav Bosne i Hercegovine (Constitution of Bosnia and Herzegovina), Aneks IV Opšteg okvirnog sporazuma za mir u Bosni i Hercegovini, Službeni glasnik BiH. Br. 25(2009) - Amandman I.

Ustav Republike Srbije (Constitution of the Republic of Serbia), Službeni glasnik RS. Br. 98 (2006).

Устав на Република Северна Македонија (Constitution of North Macedonia), Služben vesnik. 2019.

Zakon o rešavanju sukoba zakona sa propisima drugih zemalja (The Act on Resolution of Conflict of Laws with regulations of Other Countries), Službeni list SFRJ. Br. 43(1982), 72(1982) i Službeni list SRJ. Br. 46 (1996).

Zakon o zabrani diskriminacije Republike Srbije (The Anti-Discrimination Act), Službeni glasnik RS. Br. 22 (2009).

Zakon o parničnom postupku (The Contentious Proceedings Act), Službeni glasnik RS. Br. 2 (2011), 49(2013), 74 (2013), 55 (2014), (87) 2018.

Zakon o Ustavnom sudu (Constitutional Court Act), Službeni glasnik RS. Br. 109 (2007), 99 (2011), 18 (2013)...40(2015). No. 109 (2007), 99 (2011), 18 (2013)...40(2015).

Zakon o mednarodnem zasebnem pravu in postopku - ZMZPP (Private International Law Act of Slovenia), Uradni list RS. Št. 56 (1999);

Законот за меѓународно приватно право (Private International Law Act), Службен весник на Република Македонија. Бр. 87 (2007), with amendments of 
2010: Закон за изменување и дополнување, Службен весник на РМ. Бр.156 (2010)

Zakon o međunarodnom privatnom pravu Crne Gore (Private International Law Act of Montenegro), Službeni list CG. Br. 1 (2014).

Zakon o međunarodnom privatnom pravu Hrvatske (Private International Law Act of Croatia), Narodne novine. Br. 101 (2017)

Zakon o strancima (the Foreigners Act), Službeni glasnik RS, Br. 24 (2018) and 34 (2019).

Zakon o prebivalištu i boravištu građana Republike Srbije (Act on the domicile and residence of the RS citizens), Službeni glasnik RS, Br. 87 (2011)

Nacrt novog Zakona o međunarodnom privatnom pravu Republike Srbije, jun 2014 (Draft on the new Private International Law Act of the Republic of Serbia). Retrieved 21.11.2019. from https://www.mpravde.gov.rs/obavestenje/6274/ konacna

Case-Law

Affaire Mogielnicki c. Pologne (Requête no 42689/09), Arrêt du 15 septembre 2015

Cour constitutionnelle, Arrêt n 135/2018 du 11 octobre 2018, en cause: la question préjudicielle relative à l'article 851 du Code judiciaire, posée par le Tribunal de commerce de Liège, division Liège. Published in Revue belge de droit international privé, 4/2018

Case C-152/73 Sotgiu v. Deutsche Bundespost, Judgment of the CJEU of 12 February 1974.

Case C-323/95, Judgment of the Court (Sixth Chamber) of 20 March 1997 in David Charles Hayes and Jeannette Karen Hayes v Kronenberger GmbH.

Case C-122/96, Judgment of the CJEU of 2 October 1997, Stephen Austin Saldanha et MTS Securities Corporation et Hiross Holding AG.

ECtHR case Kreuz v. Poland, Judgment of 19 June 2001.

ECtHR case VM. v. Bulgaria, Judgment of 8 June 2006.

ECtHR case Tolstoy Moloslavsky v. United Kingdom, Judgment of 13 July1995 (Appl. no. 18139/91)

Rešenje Višeg trgovinskog suda, (Decision of the Higher Commercial Court) Pž. 9186/2007(1) od 22.11.2007. godine, Sudska praksa trgovinskih sudova - Bilten br. $4 / 2007$. 
Rešenje Višeg trgovinskog suda (Decision of the Higher Commercial Court), P̌̌. 7628/2004 od 6.12.2004. godine.

Rešenje Privrednog apelacionog suda (Decision of the Commercial Court of Appeal)), Pž 2616/2017 od 17.5.2017. godine, Sudska praksa privrednih sudova - Bilten br. 4/2017.

Rešenje Višeg trgovinskog suda (Decision of the Higher Commercial Court), XVIII Pž. 13836/2005 od 7.2.2006. godine.

Rešenje Privrednog apelacionog suda, (Decision of the Commercial Court of Appeal), Pž. 10770/2011(1) od 1.8.2012. godine.

Rešenje Višeg trgovinskog suda (Decision of the Higher Commercial Court), Pž. 11892/2005 od 07.02.2006. godine.

Rešenje Višeg privrednog suda (Decision of the Higher Commercial Court), Pž. 1032/2001 od 22.02.2001. godine.

Rešenje Višeg trgovinskog suda (Decision of the High Commercial Court), Pž. 8563/2003 od 22.12.2003., Sudska praksa trgovinskih sudova - Časopis za privredno pravo, 1/2004, str. 21. 


\author{
Др Сања Марјановић, \\ Доцент Правног факултета, \\ Универзитет у Нишу \\ Др Мирко Живковић, \\ Редовни професор Правног факултета, \\ Универзитет у Нишу
}

\title{
АКТОРСКА КАУЦИЈА И ЗРСЗ - ОДГОВОРНОСТ ДРЖАВЕ ЗА ДИСКРИМИНАЦИЈУ?
}

\section{Резиме}

Иако установа акторске кауције сама по себи није у супротности са правом странаца на приступ суду, она може изазвати друге једнако негативне последище. У зависности од тога како је уређена, може водити и кршењу забране дискриминације и Устава Републике Србије. Наметањем обезбеђења парничних трошкова само страним држављанима без икаквих додатних критеријума (изузев узајамности), домаћи држављани који живе у иностранству а немају имовину у Србији неоправдано се стављају у привилеговани положај. Такво законско решење обесмишљава сврху акторске кауције. Туженог, због чије заштите се акторска кауција уводи, једнако тишти неизвесност у погледу извршења судске одлуке о трошковима уколико добије спор, а тужилац нема имовинуу Србији. У таквим околностима, чињеница да тужилац има страно односно домаће држављанство постаје маргинално. Истовремено, поставља се питање уставности овако конципиране одредбе о обавези полагања акторске кауције. Стога, потребна је хитна измена одредбе члана 82 ЗРСЗ и отклањање дискриминације која је тренутно омогућена.

Кључне речи: акторска кауција, ЗРСЗ (1982), дискриминација, држављанство, Нацрт новог ЗМПП (2014). 